\title{
EFFECT OF SOME FACTORS ON WATER DISTILLATION BY SOLAR ENERGY
}

\author{
Younis, Samir M. , Mohamed H. El-Shakweer**, Mossad M. El- \\ danasary**, Adel A. Gharieb $^{* *}$ and Ragab I. Mourad**
}

\section{ABSTRACT}

Solar energy may be used for operating any desalination process to be employed directly for distillation of saline water in equipment which serves both as a solar energy absorber and as a distiller In this study, a solar distillation model is proposed and subjected for testing the concerned parameters. The parameters aimed to evaluate the distiller model performance and were: the water salinity $(28,35$ and $58 \mathrm{mmoh} / \mathrm{cm}$, $(d s / m)$, the water depth $(6,9$ and $12 \mathrm{~cm})$, the glass cover thickness (2,4 and 6mm), the percentage of daylight (43.7, 47.4 and 52.1\%), the solar radiation, the ambient air temperature, the wind speed and the relative humidity. The performance of the distiller model was characterized as the distillation yield and the collector efficiency. The maximum distillation yield was about $5 \mathrm{~L} / \mathrm{m}^{2}$.day at $6 \mathrm{~cm}$ water depth, $6 \mathrm{~mm}$ glass cover thickness, $28 \mathrm{mmoh} / \mathrm{cm}$ water salinity and $52.1 \%$ percentage of daylight (during summer season, July and August, 1997). A statistical design based on stepwise regression analysis was utilized which proved to be significant for the included variables at the level of $1 \%$ significance.

\section{INTRODUCTION}

$\mathrm{S}$ olution of water scarcity problem in many regions of Egypt is distillation of local saline water and also transporting saline water located some distance away and distillation it. Solar energy can be used as a source of heat for any distillation process. Processes employing heat can be supplied with steam from boilers heated by concentrated solar energy. Studying the possibility of utilizing solar energy for water distillation has the interest of many researchers. Many parameter effected on distillation output by solar energy.

Adhikari et al. (1995) reported that solar distillation is one of the

** Agric. Eng Dept, Faculty of Agric., Alexandria University.

** Soil and Water Sciences Dept, Fayoum Fac of Ag., Cairo University. 
important and technically viable applications of solar energy. A considerable amount of work has been done for studying the basin-type solar stills. The prototype design of such solar stills consists of a blackened water basin having a sloped transparent cover, which permits incident solar radiation to pass through it and get. Absorbed by the basin. water gets heated and the water vapors formed condense over the underside of the cover to form droplets which are collected in a trough as distilled water. Also, they reported that a computer simulation model is presented for studying the steady-state performance of a multi-stage stacked tray solar still.

Lund and Keinonen (1984); Tsilingiris (1988), and Wang and Yagoobi (1994) reported that the solar radiation plays an important role in the thermal performance of solar ponds. The solar flux incident upon a solar pond is strongly dependent on the latitude, day of year time of day, and atmospheric conditions. Also, they studied the effects of water turbidity and salt concentration levels on penetration of solar radiation under water. However, the clarity of water, quantified in terms of the turbidity level, plays a critical role on the magnitude of the solar radiation, penetration, with the effect of turbidity on solar radiation penetration increasing with water depth.

Hahn and Chen (1998) showed that the performance of a solar heating system can be improved significantly as the storage medium in the hot water store remains themerally stratified.

Gama et al. (1986) studied the analysis of a v-groove solar collector with a selective glass cover. They reported that, solar energy passing through the glass is incident of the selectively absorbing surface of the v-groove plate. The absorbed energy raises the temperature of the plate and heats air that is pumped through the triangular passages of the collector. The efficiency that can be obtained with the collector is determined as a function of a number of parameters.

Frenandez and Chargoy (1990) Claim that the rate of production of distillate was proportional to the evaporative surface in their horizontal large yields with increased evaporation areas through vertical multiple effect stills.

Adhikari et al. (1991) studied the multi-stage indirectly heated solar still. 
They reported that the yield of a solar still is always a prime design target. A rate of distilled water of about 4.5 liters per square meter of solar collector per day, typical of sloping roof still, is unfavorably compared with up to $24 \mathrm{~L} / \mathrm{m}^{2}$ of solar collector per day and even more for multistage still.

This study aims to introduce the applicability of a solar distillation model to determine the following:

1- The effect of meteorological variables on distillation output (solar radiation, relative humidity, wind speed and ambient air temperature).

2- The effect of model variables on distillation output (water salinity, water depth, and cover thickness).

3- The relation between the distillation output and the effective parameters.

\section{MATERIALS AND METHODS}

Experimental work was carried out during the period of December, 1996 to August, 1997 at the Tractors and Machinery station, Agricultural Engineering Research Institute, Al-Sabahia, Alexandria. The schematic configuration of the proposed single-sloped solar distillation model is illustrated in Fig (1). Basically, it is a direct heated solar desalination which mainly comprises a distillation unit. It consisted of a wooden box of length, width $1^{\text {st }}$ height and $2^{\text {nd }}$ height of $1.08 \mathrm{~m}, 0.1 .08 \mathrm{~m}, 0.44 \mathrm{~m}$ and $0.24 \mathrm{~m}$, respectively with a single glass cover inclined at angle of 16 degree to horizontal. A black steel box of length, width and height of 1.0 $\mathrm{m}, 1.0 \mathrm{~m}$ and $0.2 \mathrm{~m}$, respectively between the wood and the black steel. The axis of the solar distillation model was arranged to face and east-west direction and the sloped side of the suggested model was oriented south. A steel channel was fitted under the lower side of the glass cover the collect the condensed water. The channel was terminated with a small plastic pipe which drained the fresh water into an external vessel installed bellow the distillation model level. All openings in the sides of the distillation, model and joints in the glass cover and channel were well sealed with silicone rubber- sealant to prevent vapor leakage.

Three salty water sample were taken to measure their salinity values. (Electrical conductivity) using conductivity meter at the Central Laboratory of Soil and Water Analysis, Fac., of Agric., Alex., Univ. 
In this study DAS3 software program was used for data system. DAS3 program was used to measure and record the changes of temperature inside the different parts of the proposed model.

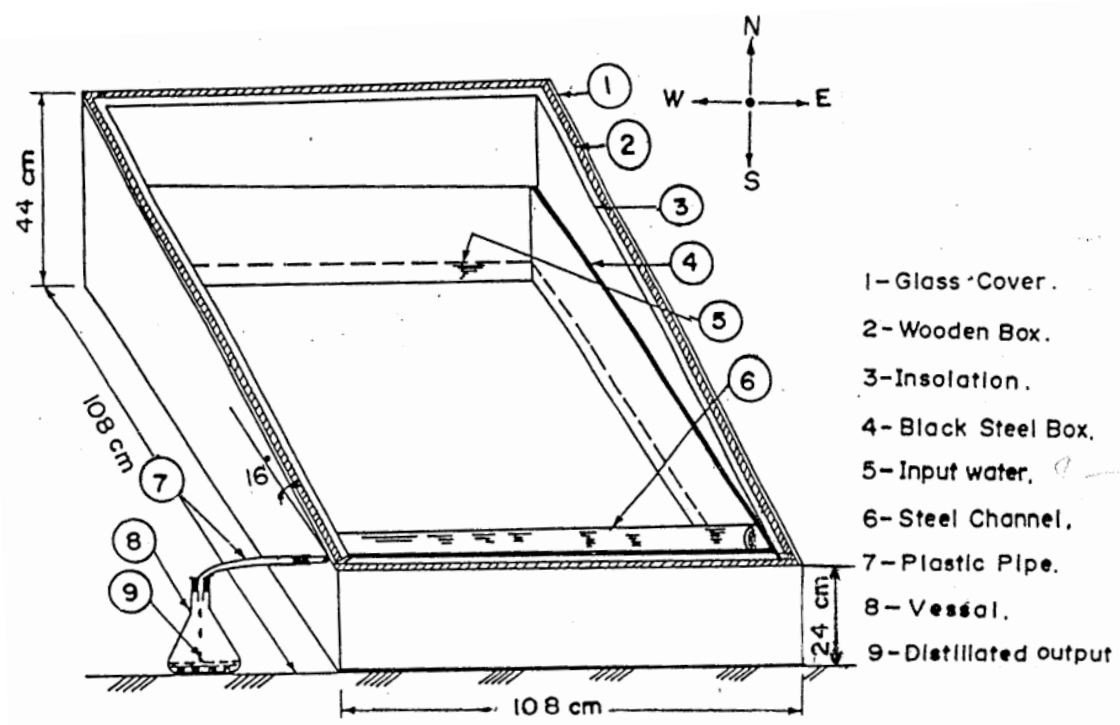

Fig (1): Schematic diagram of the suggested solar still model

Each of the experimental variables was taken at three different levels so, the sum of the experimental units would get $3^{4}=81$ treatments. The first 27 treatments were achieved at the winter season form 22 Dec., 1996 to 26 Feb., 1997; the second 27 treatments were performed at the spring season form 1 Mar., to 10 Apr., 1997; and the last 27 treatments were undertaken at the summer season from 1 July to 26 Aug., 1997, to cover the sun period range all over the year.

Collected data included solar radiation $(\mathrm{R})$, ambient air temperature $(\mathrm{T})$, wind speed (W), relative humidity (Rh), and distillation output (Q) were automatically recorded at the Meteorological station of Ministry of Agriculture Al-Sabahia, Alexandria. The distillation output percentage Was calculated as follows:

Distillation output\%
Water output (litter)/ Hr

$=\overline{\text { Total water input to the distiller model (liter) } /} \times 100$ $\mathrm{Hr}$ 


\section{RESULT AND DISCUTION}

\section{Effect of water salinity on distillation output:}

Table (1) shows the effect of water salinity on distillation output at different values of cover thickness, brine depths during winter, spring, and summer seasons. The effect of the water salinity was very pronounced on the distillation output percentage, increasing the salinity from 28 $\mathrm{mmoh} / \mathrm{cm}$

$35 \mathrm{mmoh} / \mathrm{cm}$, and then to $58 \mathrm{mmoh} / \mathrm{cm}$ decreased the distillation output percentage in the same order. Fig (2) shows the interaction effects of water salinity on distillation output at different levels of brine depth and cover thickness for the tested three periods. As it is expected the 28 $\mathrm{mmoh} / \mathrm{cm}$ salinity gave the highest distillation output percentage. However, the distillation output can increase as the water salinity decrease less

than

$28 \mathrm{mmoh} / \mathrm{cm}$ ) and the reverse is true. It is evident that with decreasing the soluble salts in water, the rate of evaporation increases which might be attributed to the weakness of ionic bonds for the low concentration of salts as compared to the medium or the high concentration of salts in water.

\section{2- Effect of brine depth on distillation output}

The data in Table (1) indicated that lower depth gave better distillation output percentage. Fig (3) shows the interaction effects of brine depth on distillation output at different levels of water salinity and cover thickness for the tested three periods. The rate of percentage increase in distillation output ranged from $8.25 \%$ to $28.38 \%$ (from 12 to $9 \mathrm{~cm}$ and from 9 the 6 cm depth).

This could be due to the effect of temperature in the $6 \mathrm{~cm}$ brine depth treatment which was more effective than 9 or $12 \mathrm{~cm}$.

\section{3- Effect of glass cover thickness of distillation output:}

Fig (4) indicated that increasing the glass cover thickness from $2 \mathrm{~mm}$, to 4 $\mathrm{mm}$ and $6 \mathrm{~mm}$, increased significantly the distillation output percentage, in the same order as the $6 \mathrm{~mm}$ glass cover thickness gave the highest distillation output percentage. This could be due to the heat loss in $.6 \mathrm{~mm}$ thickness which is less than that of 4 or $2 \mathrm{~mm}$, since it represents a high thermal resistance as compared to the other thickness. This could be 
.Table (1) The distillation output at different values of glass cover thickness, water salinity, and brine depth. during three seasons

\begin{tabular}{|c|c|c|c|c|c|}
\hline \multirow[t]{3}{*}{ Season } & \multirow[t]{3}{*}{$\begin{array}{l}\text { Glass cover } \\
\text { thickess, } \mathbf{m m}\end{array}$} & \multirow[t]{3}{*}{$\begin{array}{c}\text { Water salinity } \\
\text { mmoh/ cm }\end{array}$} & \multicolumn{3}{|c|}{$\begin{array}{l}\text { Distillation output at different } \\
\text { water depth }\end{array}$} \\
\hline & & & $6 \mathrm{~cm}$ & $9 \mathrm{~cm}$ & $12 \mathrm{~cm}$ \\
\hline & & & $\begin{array}{c}\mathrm{L} / \mathrm{m}^{2} \text {. } \\
\text { day }\end{array}$ & $\begin{array}{c}\mathrm{L} / \mathbf{m}^{2} \text {. } \\
\text { day }\end{array}$ & $\begin{array}{c}\mathrm{L} / \mathbf{m}^{2} \text {. } \\
\text { day }\end{array}$ \\
\hline \multirow{9}{*}{$\begin{array}{c}\text { Winter } \\
\text { Des, Jan, Feb }\end{array}$} & 2 & 28 & 2.4 & 1.8 & 1.6 \\
\hline & 2 & 35 & 2.3 & 1.6 & 1.3 \\
\hline & 2 & 58 & 2.0 & 1.4 & 1.0 \\
\hline & 4 & 28 & 2.7 & 2.0 & 1.8 \\
\hline & 4 & 35 & 1.9 & 1.5 & 0.8 \\
\hline & 4 & 58 & 1.3 & 1.2 & 0.6 \\
\hline & 6 & 28 & 3.2 & 2.4 & 2.0 \\
\hline & 6 & 35 & 2.8 & 2.0 & 1.6 \\
\hline & 6 & 58 & 2.6 & 1.8 & 1.4 \\
\hline \multirow{9}{*}{$\begin{array}{l}\text { Spring March, } \\
\text { April1 }\end{array}$} & 2 & 28 & 3.1 & 2.3 & 1.9 \\
\hline & 2 & 35 & 2.6 & 2.3 & 1.7 \\
\hline & 2 & 58 & 2.4 & 2.0 & 1.5 \\
\hline & 4 & 28 & 3.3 & 3.1 & 2.1 \\
\hline & 4 & 35 & 3.0 & 2.9 & 1.9 \\
\hline & 4 & 58 & 2.9 & 3.6 & 1.6 \\
\hline & 6 & 28 & 3.9 & 3.2 & 2.9 \\
\hline & 6 & 35 & 3.5 & 2.8 & 2.4 \\
\hline & 6 & 58 & 3.0 & 2.7 & 2.2 \\
\hline \multirow{9}{*}{$\begin{array}{c}\text { Summer July, } \\
\text { August }\end{array}$} & 2 & 28 & 4.3 & 3.4 & 3.0 \\
\hline & 2 & 35 & 3.4 & 3.0 & 2.7 \\
\hline & 2 & 58 & 3.1 & 2.8 & 2.0 \\
\hline & 4 & 28 & 4.8 & 3.7 & 3.2 \\
\hline & 4 & 35 & 3.8 & 3.3 & 3.0 \\
\hline & 4 & 58 & 3.3 & 3.0 & 2.4 \\
\hline & 6 & 28 & 5.1 & 3.9 & 3.1 \\
\hline & 6 & 35 & 4.1 & 3.7 & 2.9 \\
\hline & 6 & 58 & 3.7 & 3.6 & 2.6 \\
\hline
\end{tabular}

explained as the input quantity of heat to $2 \mathrm{~mm}, 4 \mathrm{~mm}$ and $6 \mathrm{~mm}$ glass thickness are equally, this due to the approximately equally, this due to the approximately equally of transmittance and absorptance.

\section{4- Effect of meteorological variables on distillation of model:}

There are many factors of meteorological conditions, such as solar radiation, relative humidity, ambient air temperature, and wind speed which may be affect on distiller performance 


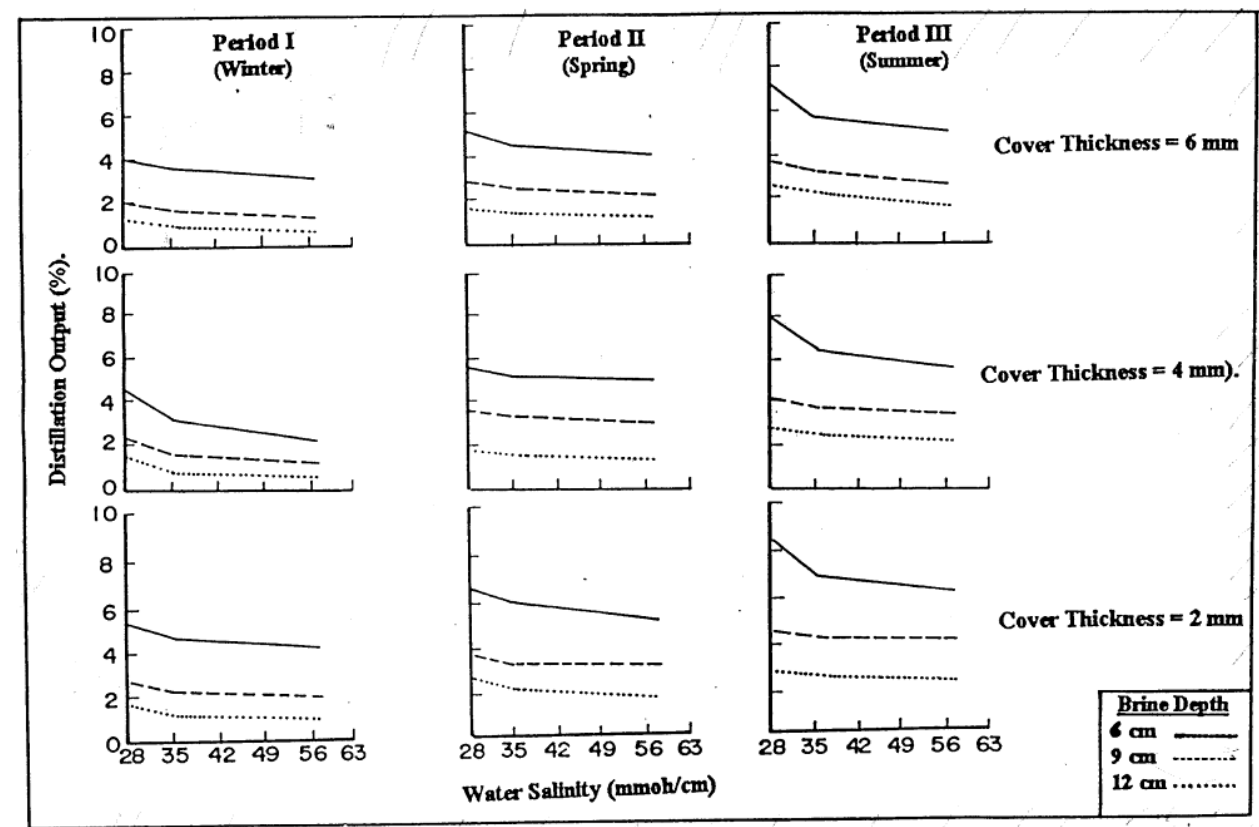

Fig (2) The Interaction effect of water salinity on distillation output at different levels of brine depth and cover thickness for three periods of daylight percentage

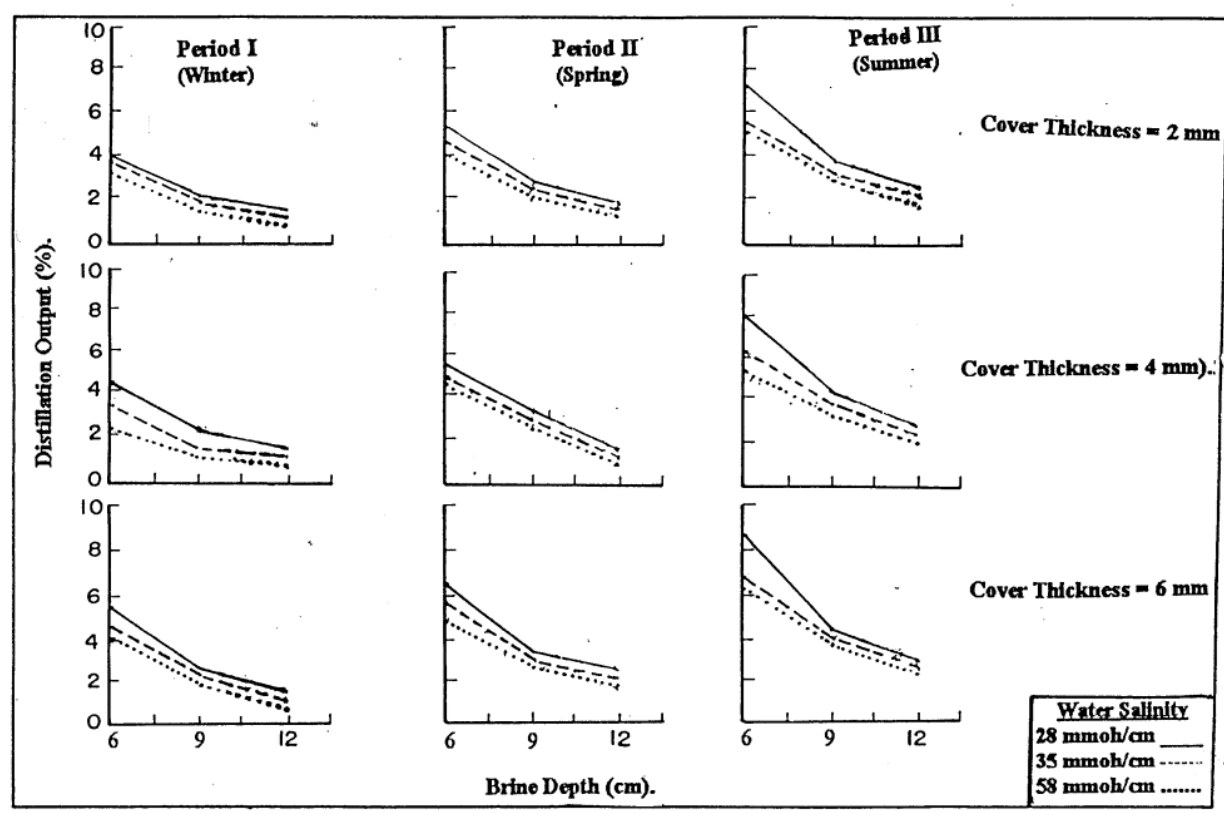

Fig (3) The Interaction effect of brine depth on distillation output at different levels of water salinity and cover thickness for three periods of daylight percentage 


\section{A- Effect of solar radiation:}

Fig (5-A) shows the effect of the solar radiation on the distillation output. In general, the distillation output increased as the solar radiation increased. The highest distillation output was obtained during summer season (July and August). But the minimum distillation output was at winter season (Dec., Jan., and Feb.) to get accurate mathematical expression of the relation between solar radiation and distillation output, one equation was developed to best fit for all groups of data of the tested three periods utilizing the graphic statistical software. The following equation was formed:

\section{Where:}

$$
Q=0.037 R^{0.705}
$$

$\mathrm{Q}$ is the distillation output, $\mathrm{L} / \mathrm{m}^{2}$. day.

$\mathrm{R}$ is the solar radiation, $\mathrm{W} / \mathrm{m}^{2}$. day.

\section{B- Effect of ambient air temperature:}

Fig (5-B) shows the effect of the ambient air temperature on the distillation output. It is clearly seen that increasing of distillation output was slight as the ambient air temperature increased. The following equation was consulted:

\section{Where:}

$$
Q=0.263 T^{0.783}
$$

$\mathrm{T}$ is ambient air temperature, ${ }^{\circ} \mathrm{C}$,

\section{Effect of wind speed}

Fig (5-C) shows the effect of wind speed on the distillation output. Distillation output appears to decrease slightly as wind speed increases.

The resulted equation from the data was as follows:

$$
Q=2.533 \mathrm{e}^{-0.036 \mathrm{~W}}
$$

\section{Where:}

$\mathrm{W}$ is the wind speed, $\mathrm{m} / \mathrm{s}$.

\section{D- Effect of relative humidity:}

Effect of relative humidity is given on Fig (5-D). The effect of relative humidity was pronounced on the distillation output. Little of increasing the distillation output was observed by decreasing relative humidity. The resulted equation was:

\section{Where:}

$$
Q=4.586 \mathrm{Rh}^{-0.143}
$$

$\mathrm{Rh}$ is relative humidity $\%$. 


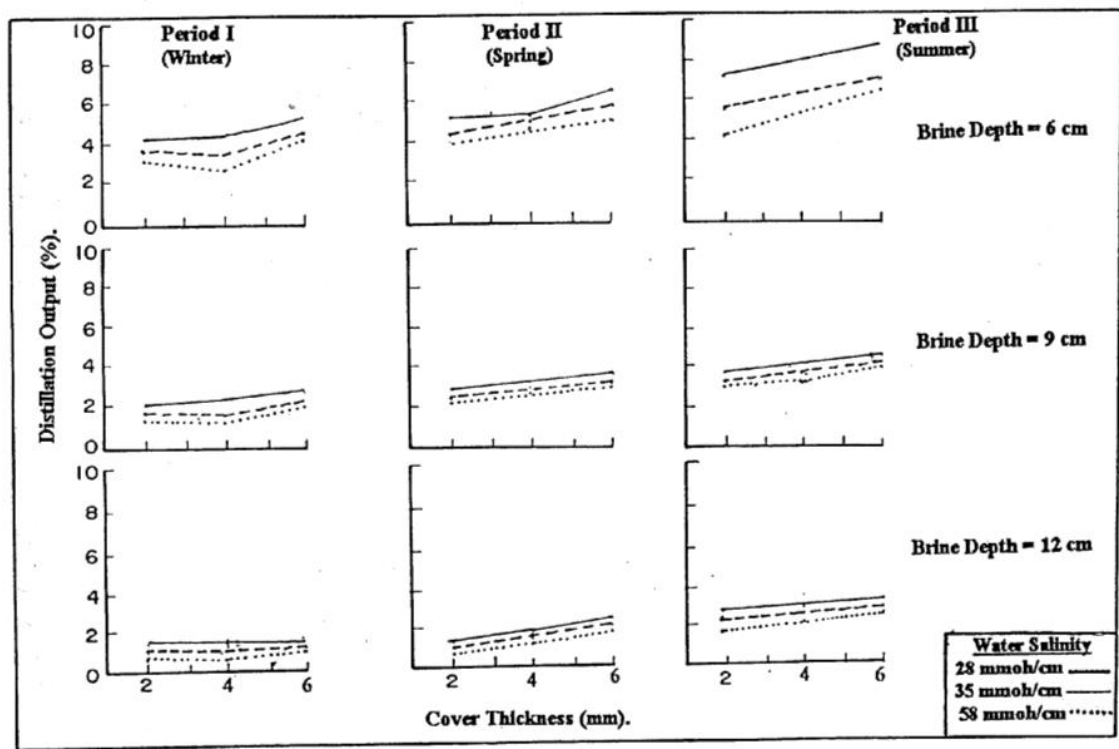

Fig (4) The Interaction effect of cover thickness on distillation output at different levels of brain depth and water salinity for three periods of daylight percentage

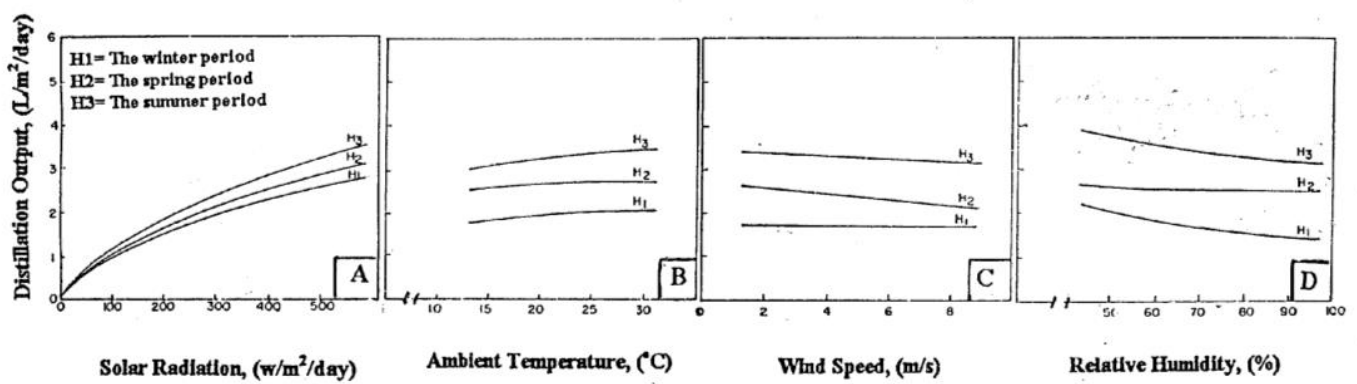

Fig (5) Effect of solar Radiation, Ambient Temperature, Wind speed and Relative Humidity on Distillation output the Experimental periods (H1, H2 an H3)

\section{5- Statistical Analysis of the parameters of the solar distillation:}

The effect of the individual (percentage of daylight, glass cover thickness, initial water depth, water salinity), and their interactions on the distillate output were statistically analyzed. A simple statistical program was developed, utilizing the SAS packages. The correlation and stepwise regression analyses were applied to find a reasonable good set of the 
independent variables.

The criterion for adding or deleting an independent variable can be stated equivalently in terms of error of square reduction, coefficient of partial correlation, or F statistics. Table (2) shows the final regression model with the set of independent variables. The concluded regression equation could be shown as follows:

$$
\begin{gathered}
Q=0.002+0.011 T-0.042 W+0.08 H+137.93 C-0.03 S-17.90 D \\
\left(R^{2}=89 \%\right)
\end{gathered}
$$

\section{Where:}

$\mathrm{Q}$ is the distillation output, $\mathrm{L} / \mathrm{m} 2$.day

$\mathrm{H}$ is the percentage of daylight $\%$.

$\mathrm{C}$ is the glass cover thickness, $\mathrm{m}$

$\mathrm{S}$ is the water salinity (electrical conductivity), mmoh,cm, D is the initial water depth inside the distiller, $\mathrm{m}$

$\mathrm{T}$ is the ambient air temperature, ${ }^{\circ} \mathrm{C}$

\section{$R$ is the solar radiation, $w / \mathbf{m} 2$.day}

$\mathrm{W}$ is the wind speed $\mathrm{m} / \mathrm{s}$

The model has shown the significance of all individual variables at significant level of $1 \%$. No interactions or high order of any variable appeared to be of any significance. The model has shown the importance of the variables as the global solar radiation, initial water depth, percentage of daylight, water salinity, glass cover thickness, then ambient air temperature, the coefficient of determination R2 for the final model was $89 \%$ Fig (6) shows the relation between observed and predicted data from the statistical model.

\section{CONCLUSION}

\section{The obtained results indicated the following:}

1. Distillation yield decreased as water salinity increased, as the yield increased from $3.7 \mathrm{~L} / \mathrm{m} 2$.day to $4.1 \mathrm{~L} / \mathrm{m} 2$.day as salinity decreased from

$58 \mathrm{mmoh} / \mathrm{cm}$ to $35 \mathrm{mmoh} / \mathrm{cm}$, also, the yield increased from $4.1 \mathrm{~L} / \mathrm{m} 2$.day to $5.1 \mathrm{~L} / \mathrm{m} 2$.day as salinity decreased from $35 \mathrm{mmoh} / \mathrm{cm}$ to $28 \mathrm{mmoh} / \mathrm{cm}$, at $6 \mathrm{~cm}$ initial water depth, $6 \mathrm{~mm}$ cover thickness and daylight percentage about $52.1 \%$. 
Table (2): The regression model for depended variable :Q

\begin{tabular}{|c|c|c|c|c|}
\hline Parameters & Estimate & $\begin{array}{c}\text { T for HO: } \\
\text { Parameter } \\
\mathbf{0 . 0}\end{array}$ & Rr> T & $\begin{array}{c}\text { std error of } \\
\text { estimate }\end{array}$ \\
\hline H & 0.08 & 7.645 & 0.0001 & 0.0112 \\
\hline C & 137.93 & 6.017 & 0.0001 & 22.923 \\
\hline S & -0.03 & -8.688 & 0.0001 & 0.0028 \\
\hline D & -17.9 & -11.72 & 0.0001 & 1.5231 \\
\hline R & 0.002 & 3.983 & 0.0002 & 0.0005 \\
\hline T & 0.011 & 1.036 & 0.3038 & 0.0108 \\
\hline W & -0.042 & -1.653 & 0.1027 & 0.0251 \\
\hline
\end{tabular}

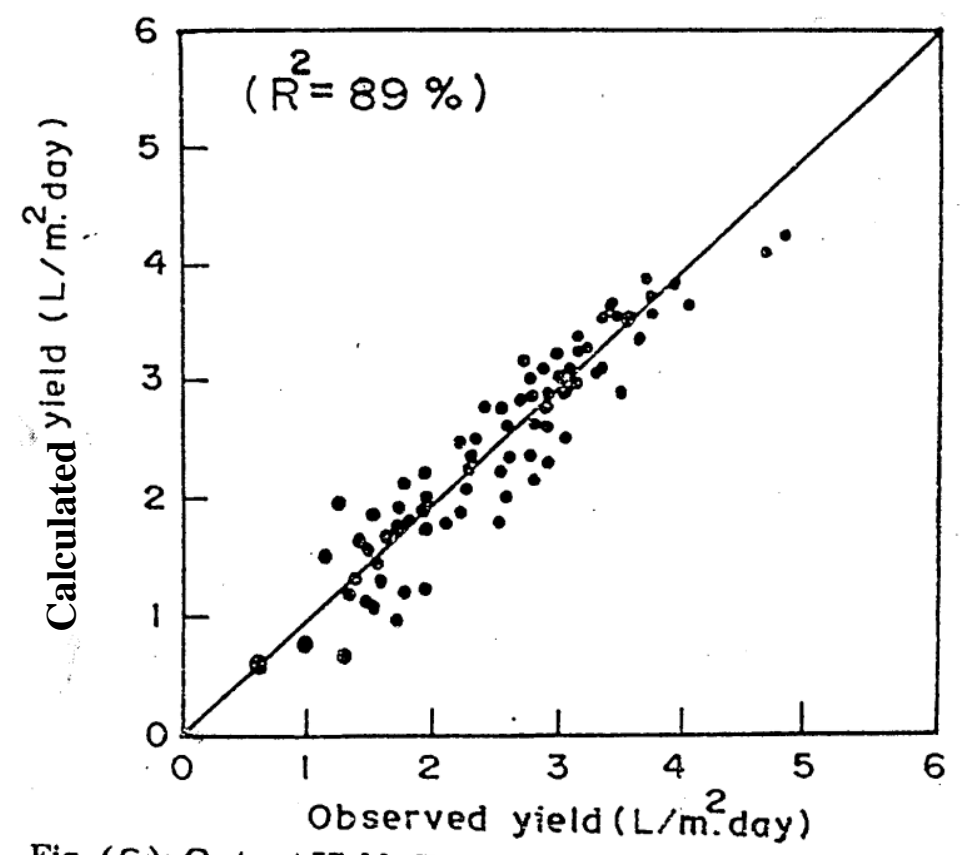

Fig. (6): Output Yields Predicted From The Statistical Equation And The Observed Yields During The Experimental Periods 
2. The distillation output increased as the water depth decreased, where the maximum distillation output was at $6 \mathrm{~cm}$ water depth.

3. The distillation. rate of the model increased as glass cover thickness increased, where the distillation output increased from $4.3 \mathrm{~L} / \mathrm{m} 2$.day to $5.1 \mathrm{~L} / \mathrm{m} 2$.day as cover thickness increased from $2 \mathrm{~mm}$ to $6 \mathrm{~mm}$, at 6 $\mathrm{cm}$ initial water depth, and $28 \mathrm{mmoh} / \mathrm{cm}$ water salinity.

4. The high value of ambient air temperature and solar radiation increased distillation output. But the high wind speed and high relative humidity tended to decrease the distillation output.

5. The performed statistical analysis revealed that all of the variables in the statistical model gave significant effects on the distillation yield at the level of significant $0.1 \%$ the obtained statistical regression equation was as follows:

$$
\begin{array}{r}
\mathrm{Q}=0.002 \mathrm{R}+0.011 \mathrm{~T}-0.042 \mathrm{~W}+0.08 \mathrm{H}+137.93 \mathrm{C}-0.03 \mathrm{~S}-17.90 \mathrm{D} \\
(\mathrm{R} 2=89 \%)
\end{array}
$$

\section{Where:}

$\mathrm{Q}$ is the distillation output, $\mathrm{L} / \mathrm{m} 2$.day; $\mathrm{H}$ is the percentage of daylight $\%$.; $\mathrm{C}$ is the glass cover thickness, $\mathrm{m}$; $\mathrm{S}$ is the water salinity (electrical conductivity), mmoh, $\mathrm{cm}$, ; D is the initial water depth inside the distiller, $\mathrm{m} ; \mathrm{T}$ is the ambient air temperature, ${ }^{\circ} \mathrm{C} ; \mathrm{R}$ is the solar radiation, $\mathrm{w} / \mathrm{m}^{2}$.day ; and $\mathrm{W}$ is the wind speed $\mathrm{m} / \mathrm{s}$.

\section{REFERENCE}

Adhikari, R.S.; Humar, A., and M.S. Sodha (1991) Thermal performance of a multi-effect diffusion solar still. Energy Research, 15, 769 779.

Adhikari, R.S.; Kumar, A., and G.D. Sootha (1995). Simulation studies on a multi-stage stacked tray solar still. Solar Energy 154 (5): 317-325.

Frenandez, J. L. and N. Chargoy (1990). Multi-stage indirectly heated solar still. Solar Energy J. 44 (4): 215-223.

Gama, R.M; J. A. O., Pessamha, 1A,.Parise, R. and F.E. Saboya. (1986) Analysis of $\mathrm{V}$-groove solar collector with a selective glass cover. Solar Energy J. 63 (6): 509-519.

Hahna and Y. Chen (1998). Numerical study of flow heat transfer 
Charachteristics_in hot water stores. Solar Energy J. 64 (1):9-18.

Harprect, S.K. (1996) Performance of a solar still: predicted effect of enhanced evaporation area on yield and evaporation temperature. Solar Energy J. 56(3): 261-266.

Hollands, C.E. and M.F. lightstone (1989) A review of low-flow, stratified tank solar water heating systems. Solar Energy J. 43 (2): 97-105.

Kishore, V.V.N.; M.R. Gandhi and K .S. Rao (1986) Experimental and analytical studies of shallow solar pond systems with continuous heat extraction. Solar Energy J. 36 (3): 245-256.

Lund, P.D. and R.S. Keinonen (1984) Radiation transmission measurements for solar ponds. Solar Energy J. 33 (3): 237-240.

Mourad, Ragab. I. (2002). Effect of some factors in water distillation by solar energy. Ph. D thesis, Fayoum Faculty of Agriculture, University of Cairo 2000.

Tsilingiris, P.T. (1988) An accurate upper estimate for the transmission of solar radiation in salt gradient ponds. Solar Energy J. 40 (1): 41-48

Wang, J. and J. S. Yagoobi (1994) Effects of water turbidity and salt concentration levels 0 penetration of solar radiation under water. Solar Energy J.52 (5): 429-438.

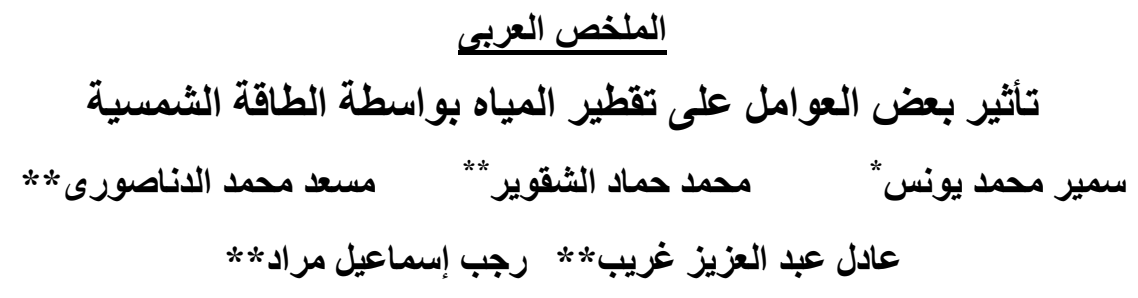

كثير اً من المناطق فى مصر تعانى من عدم و جود المياه العذبة بر غم تو افر المياه المالحة بها، مما

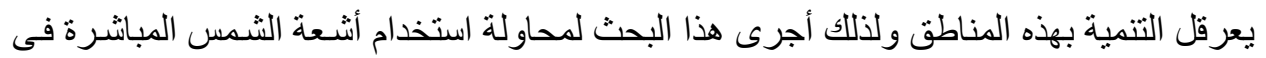

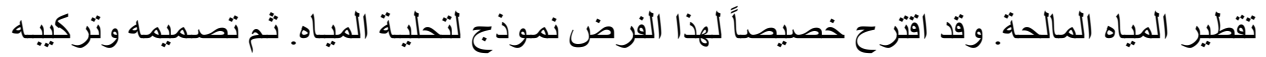

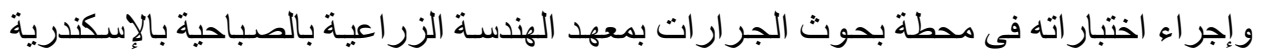

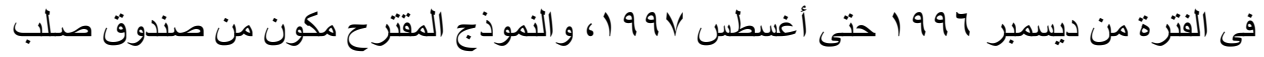

$$
\text { قسم الهندسة الزراعية ـ كلبة الزر اعة - جامعة الإسكندرية. }
$$
قسم علوم الأر اضى و المباه كلية الزر اعة بالفيوم - جامعة القية القاهرة. 


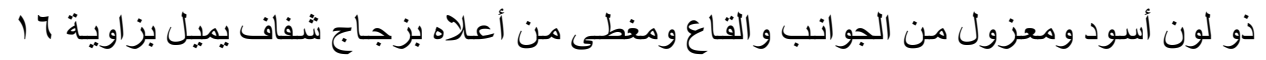

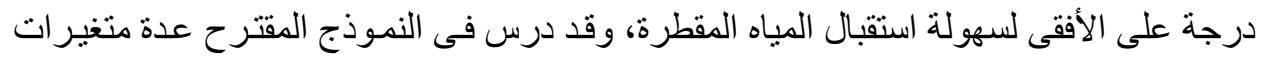

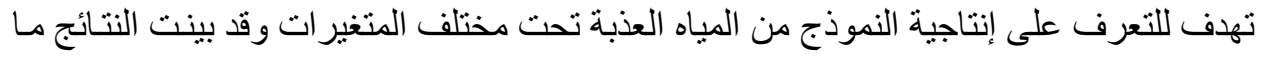
يلى : ا ــ تناقص كمية المياه المقطرة بزيادة درجة ملوحة المياه المستخدمة فقد كانت إنتاجية المياه

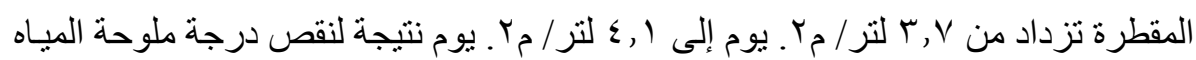

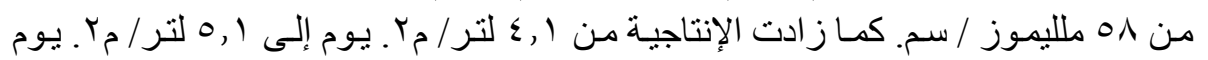

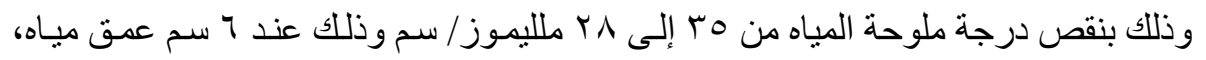

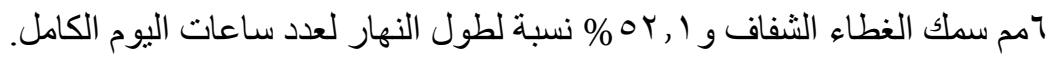

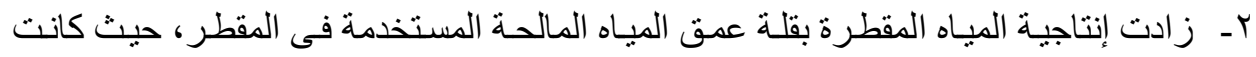

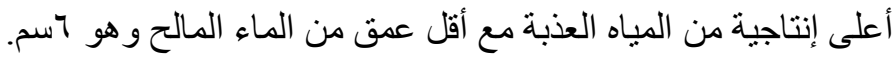

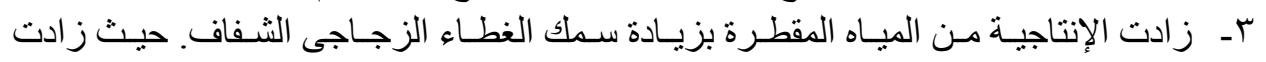

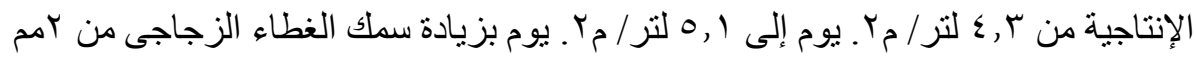

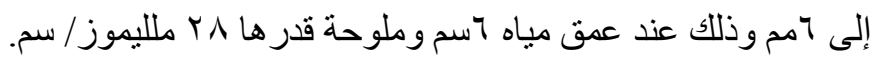

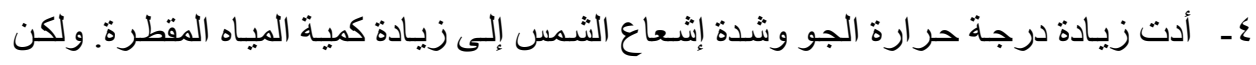

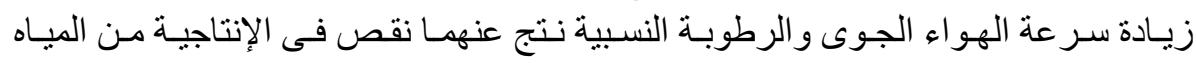

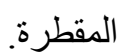

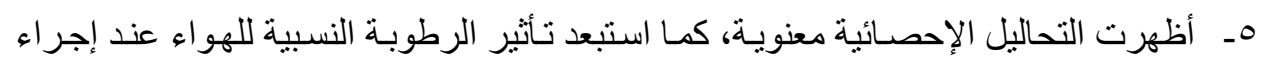
stepwise regression analy $Q=0.002 R+0.011 T-0.042 W+0.08 H+137.93 C-0.03 S-17.90 D$

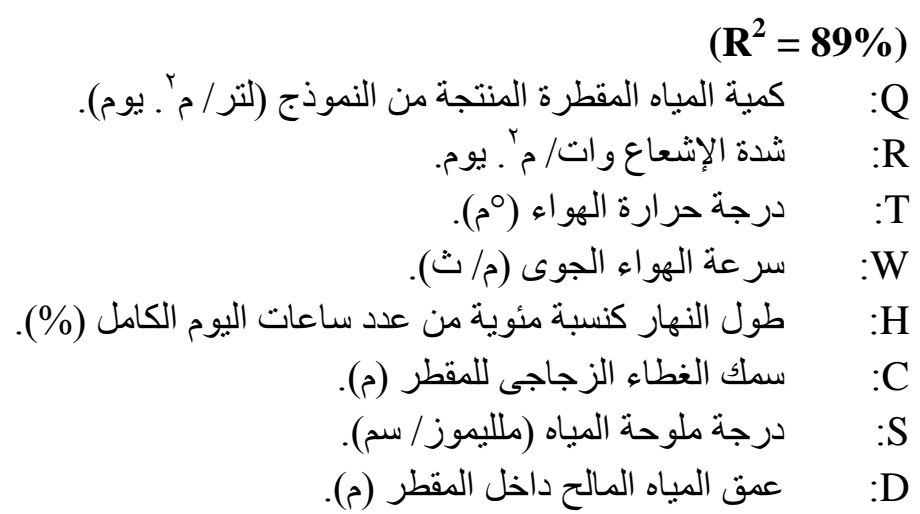

